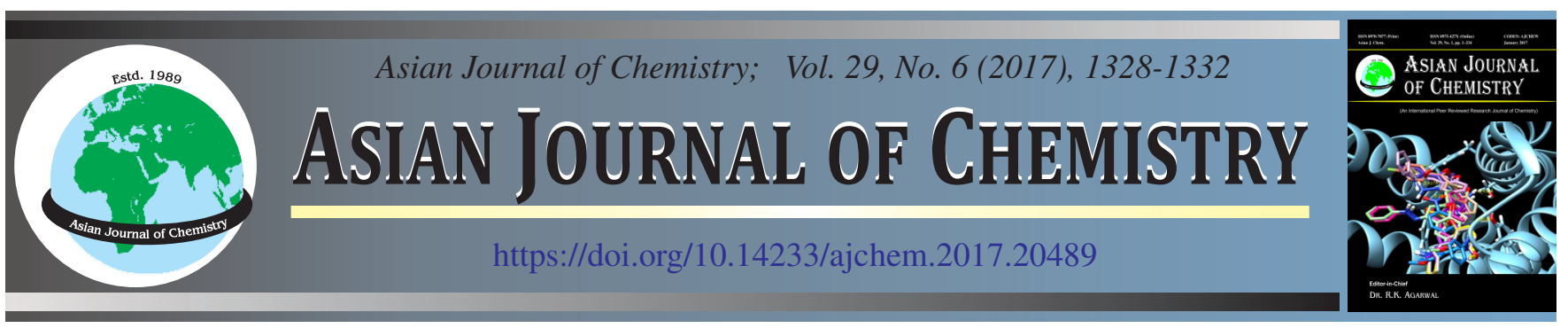

\title{
Spectrophotometric Determination of Bi(III) from Alloys and Drugs Samples Using Pyridine-2-carboxaldehyde-2-hydroxybenzoylhydrazone
}

\author{
Murli N. Bale ${ }^{1}$, Arun D. Sawant ${ }^{1}$, Hamid Shaikh ${ }^{2}$ and Dipak J. Garole ${ }^{3, *}$
}

${ }^{1}$ Inorganic Chemistry Division, The Institute of Science, Madam Cama Road, Mumbai-440 020, India

${ }^{2}$ SABIC Polymer Research Center, Chemical Engineering Department, King Saud University, P. O. Box 800, Riyadh 11421, Saudi Arabia

${ }^{3}$ Directorate of Geology \& Mining, Government of Maharashtra, Nagpur-440 010, India

*Corresponding author: E-mail: drdipakgarole@rediffmail.com

Received: 3 January 2017;

Accepted: 14 March 2017;

Published online: 10 April 2017;

AJC-18348

\begin{abstract}
A simple, rapid and selective spectrophotometric method was developed for the determination of Bi(III) with pyridine-2-carboxaldehyde 2-hydroxybenzoylhydrazone (PAHB) as a chelating reagent. The proposed method has been described on the basis of selective extraction of $\mathrm{Bi}(\mathrm{III})$ at $\mathrm{pH}$ range 2-3, showed yellow-green coloured complex having molar ratio 1:2. The equilibrium time is 1 min for extraction of $\mathrm{Bi}(\mathrm{III})$ from aqueous phase. The absorbance of coloured organic layer in chloroform is measured spectrophotometrically at $380 \mathrm{~nm}$ against reagent blank. The Beers law was obeyed in the concentration range $0.7-4.3 \mu \mathrm{g} \mathrm{mL}^{-1}$ and optimum concentration range was 0.9 $4.0 \mathrm{ppm}$ of $\mathrm{Bi}(\mathrm{III})$. Molar absorptivity and Sandells sensitivity of $\mathrm{Bi}(\mathrm{III})$-pyridine-2-carboxaldehyde 2-hydroxybenzoylhydrazone complex in chloroform are $3.46 \times 10^{4} \mathrm{~L} \mathrm{~mol}^{-1} \mathrm{~cm}^{-1}$ and $6.0 \mathrm{ng}$ respectively. The composition of extracted species was determined jobs continuous variation method, mole ratio and slope ratio method. The complex was stable for 6 days. The interference effect of cation and anion were also studied. The method is successfully applied for the determination of Bi(III) in binary, synthetic mixtures and real pharmaceutical samples. The accuracy and reliability of method was verified by AAS. This method is found to be rapid and reproducible.
\end{abstract}

Keywords: Bismuth, Solvent extraction, Pyridine-2-carboxaldehyde 2-hydroxybenzoylhydrazone, Alloy sample analysis.

ᄂ - - - - - - - - - - - - - - - - - - - - - - - - -

\section{INTRODUCTION}

Bismuth and its compounds are comparatively less abundant in soil $(0.00002 \%)$. But it is used in different area of life such as cosmetic industry, medicines, alloys, by-product of copper and tin refining, metallurgical additives and preparation and recycling of uranium in nuclear fuels, fabrication of catalyst [1]. The pharmaceutical uses of some of its colloidal salts have expanded to antacids, peptic ulcer treatments, radiotherapeutic agents and topical dermatological creams [2]. Although bismuth exposure is common, that does not mean it's completely harmless. A number of toxic effects in human beings such as nephrotoxicity, neurotoxicity, kidney damage and nephropathy have been reported for the use of bismuthcontaining pharmaceuticals. As the use of bismuth and its compounds in different areas of life has increased, its presence in the environment and the chance of bismuth exposure to organisms has also increased. Therefore, due to the presence of bismuth in environmental and biological samples at low levels, the demand for sensitive, low cost, rapid and reliable analytical methods for the preconcentration and determination of this element has increased.
A variety of techniques have been developed for the determination of bismuth in different samples. These include inductively-coupled plasma mass spectrometry $[3,4]$, inductively-coupled plasma optical emission spectrometry $[5,6]$, voltammetry $[7,8], \mathrm{X}$-ray fluorescence $[9,10]$, spectrophotometry [11], hydride generation atomic absorption spectrometry [12] and flame atomic absorption spectrometry $[13,14]$ electrothermal atomic absorption spectrometry [15].

Among the above mentioned techniques, direct determination of elements at trace levels is easy only when ICPMS is used. However, ICP-MS could not found commonly in laboratory because of its high instrument cost. On other side, UV-visible spectrophotometry is the simplest and most costeffective technique for routine analysis and is also available in many laboratories. However, direct determination of bismuth by UV-visible spectrophotometry is seldom carried out due to the relatively poor sensitivity of this approach. Thus, a sample preconcentration step before the detection of bismuth by UVvisible spectrophotometry is often required. Literatures survey revealed many solvent extraction process used for the determination of bismuth [16-24]. 
EXPERIMENTAL

A digital $\mathrm{pH}$ meter was used for $\mathrm{pH}$ measurement (Elico pH meter, model Li-120). Meddler analytical single pan balance model having accuracy $0.001 \mathrm{~g}$ was used for weighing operation. A Shimadzu UV-visible double beam spectrophotometer 2400 with $1 \mathrm{~cm}$ quartz cell used for absorbance measurement.

All the reagents were analytical grade and used as received without further purification.

Bismuth(III) solution: A standard stock solution of bismuth(III) $\left(5 \mathrm{mg} \mathrm{mL}^{-1}\right)$ was prepared by dissolving calculated amount of bismuth nitrate (Merck) in $5 \mathrm{~mL}$ concentrated nitric acid and diluted to $1000 \mathrm{~mL}$ with distilled water and standardized [25].

The working solution was prepared by appropriate dilution of stock solution with distilled water.

Pyridine-2-carboxaldehyde 2-hydroxybenzoylhydrazone (PAHB) solution and various ion solutions: A $1 \%(\mathrm{w} / \mathrm{v})$ solution of PAHB was prepared by dissolving in dimethyl formamide (DMF). All the standard solutions of metal ions used to study the effect of diverse ions were prepared by dissolving weighed quantity of their salts in concentrated acids and then diluted with distilled water. The solution of anions was prepared by dissolving their respective alkali metal salts in distilled water. The double distilled water was used throughout the experiment.

General extraction and determination procedure for bismuth(III): To $1 \mathrm{~mL}$ aliquot of aqueous solution containing $60 \mu \mathrm{g}$ of bismuth(III), few $\mathrm{mL}$ of distilled water was added and the $\mathrm{pH}$ was adjusted to required value by dilute solution of nitric acid and sodium hydroxide. The solution was diluted to $10 \mathrm{~mL}$ and was equilibrated with for $1 \mathrm{~min}$ with $10 \mathrm{~mL}$ of chloroform contains $0.5 \mathrm{~mL}$ of $1 \%$ PAHB in $N, N$ '-dimethyl formamide. Bismuth in organic phase was back extracted into $10 \mathrm{~mL}$ of $0.2 \mathrm{~N}$ nitric acid. Bismuth content in both the phases was estimated spectrophotometrically with potassium iodide [26] or by atomic absorption spectrophotometrically (AAS).

\section{RESULTS AND DISCUSSION}

Formation of complex and its spectral characteristics A yellow-green colour complex of $\mathrm{Bi}$ (III) was formed with pyridine-2-carboxaldehyde 2-hydroxybenzoylhydrazone (PAHB) in DMF. It is extracted in chloroform and analyzed for UV measurement. It is observed that this $\mathrm{Bi}(\mathrm{III})$ complex shows the maximum absorbance at $380 \mathrm{~nm}$. The spectra of the reagent and coloured complex are shown in (Fig. 1).

Study of extraction efficiency as a function of $\mathbf{p H}$ : The extraction efficiency of bismuth ion is highly depending on the $\mathrm{pH}$ of the medium. To study this effect, extraction of very low concentration of bismuth $(60 \mu \mathrm{g})$ was carried out at $\mathrm{pH}$ varying from 1 to 7 using chloroform which contains $1 \mathrm{~mL}$ of $1 \%$ PAHB in DMF. The quantitative extraction (99.9\%) of bismuth(III) between pH 2 to 3 is shown in Fig. 2 .

Effect of solvents: A variety of solvents were tried to study their suitability and adequacy for the extraction of bismuth(III). Chloroform and 1,2-dichlorobenzene were found to be the most suitable solvents. The extraction of bismuth(III) varied

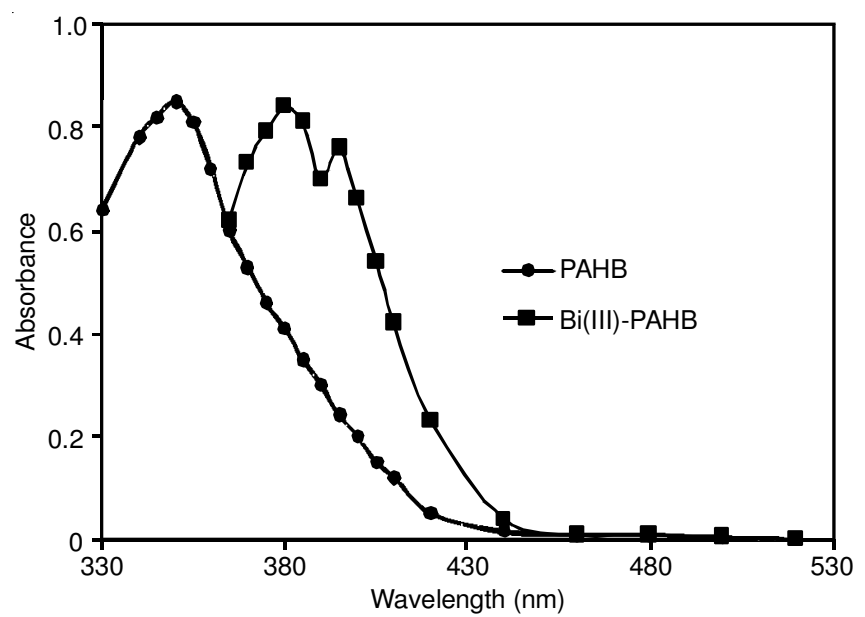

Fig. 1. Absorption spectra of PAHB and bismuth(III)-PAHB in chloroform

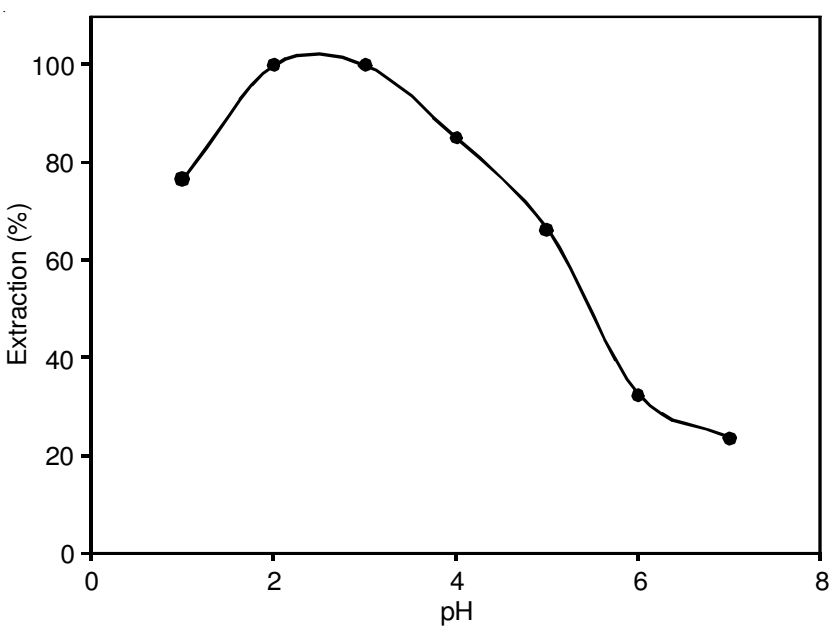

Fig. 2. Extraction of Bismuth(III) as function of $\mathrm{pH}$

from the maximum $99.9 \%$ to a minimum of $10.4 \%$ for solvents in the order of chloroform is $=1,2$-dichlorobenzene $>$ carbon tetrachloride $>$ tetrachloroethane $>1$,2-dichloroethane $>$ benzene $>$ isobutyl methyl ketone $>$ toluene $>$ xylene $>$ ethyl acetate (Table-1).

\begin{tabular}{lcc}
\multicolumn{3}{c}{ TABLE-1 } \\
\multicolumn{1}{c}{ EXTRACTION COEFFICIENTS OF Bi(III) } \\
WITH PAHB IN VARIOUS SOLVENTS \\
\hline \multicolumn{1}{c}{ Solvent } & Extraction & Extraction (\%) \\
\hline Ethyl acetate & 0.1 & 10.4 \\
Xylene & 0.2 & 18.2 \\
Toluene & 0.3 & 23.4 \\
Isobutyl methyl ketone & 1.0 & 50.6 \\
Benzene & 4.1 & 80.5 \\
1,2-Dichloroethane & 6.7 & 87.0 \\
Tetrachloroethane & 14.3 & 93.5 \\
Carbon tetrachloride & 14.3 & 93.5 \\
1,2-Dichlorobenzene & 999.0 & 99.9 \\
Chloroform & 999.0 & 99.9 \\
\hline
\end{tabular}

Effect of PAHB concentration: The concentration of PAHB in DMF was varied within the range $2.07 \times 10^{-4}$ to 2.90 $\times 10^{-3} \mathrm{~mol} \mathrm{~L}^{-1}$. The reagent was added into $60 \mu \mathrm{g} \mathrm{mL} \mathrm{m}^{-1}$ of bismuth(III) ion solution. Absorbance was measured according to the developed procedure. It was observed that $1 \mathrm{~mL}$ of $1 \%$ 
reagent concentration was required for full colour development. There is no significant change in the absorption with excess of the reagent concentration shown in Fig. 3.

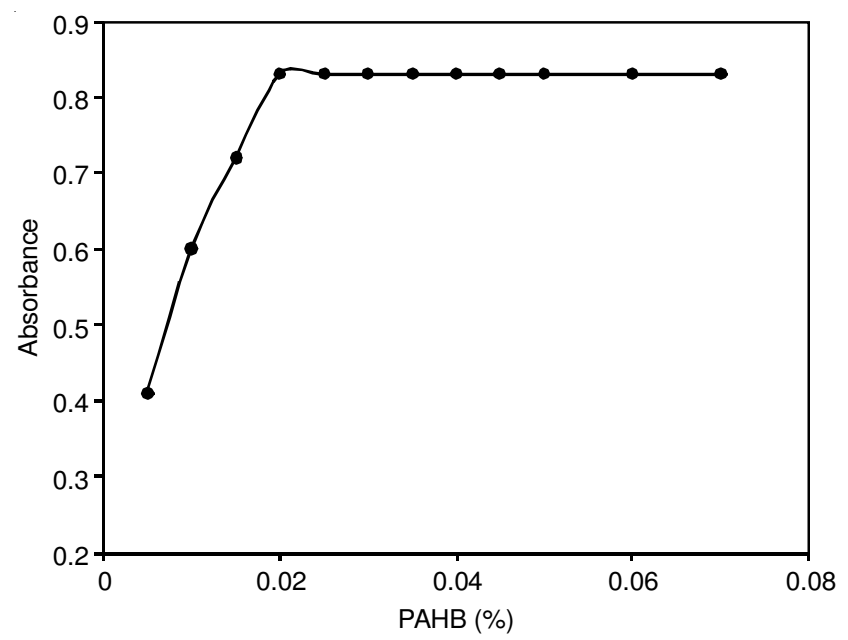

Fig. 3. Extraction behaviour of bismuth(II) as function of PAHB concentration

Effect of shaking time: The optimum shaking time of $30 \mathrm{~s}$ was determined by varying the shaking time from 10 to 240 s. prolonged shaking has no adverse effect on the extraction of bismuth(III). Hence, a shaking time of $60 \mathrm{~s}$ was selected for subsequent experiment.

Effect of colour stability of complex: The colour stability was studied at room temperature by measuring the absorbance at regular time intervals. The absorbance of bismuth(III)-PAHB complex in chloroform was stable for 6 days.

Beers law, sensitivity, precision and accuracy of the method: The absorbance of the extracted species was a linear function of bismuth(III) concentration in the range of 0.7-4.3 $\mathrm{ppm}$ at $380 \mathrm{~nm}$. The optimum working range found to be $0.9-$ $4.0 \mathrm{ppm}$. The Sandells sensitivity of the method was found to be $6.0 \mathrm{ng} \mathrm{cm}^{-2}$, while molar absorptivity was $3.46 \times 10^{4} \mathrm{~mol}^{-1}$ $\mathrm{cm}^{-1}$. The precision and accuracy of the method were determined by analyzing the solutions containing known amount of bismuth(III). The average of 10 determinations of $60 \mu \mathrm{g}$ of bismuth(III) was $59.95 \mu \mathrm{g}$ with standard deviation 0.13 and variance 0.02 . Variation from mean at $95 \%$ confident limit was $59.95 \pm 0.20$.

Composition of the complex: The composition of complex was studied in the excess of reagent solution by the sloperatio (Fig. 4). A break at a 1:3 (M:L) mole ratio suggested the formation of complex where $\mathrm{M}=\mathrm{Bi}(\mathrm{II})$ and $\mathrm{L}=\mathrm{PAHB}$ under the given conditions.

Effect of foreign ions: The selectivity of the method was investigated by the determination of $60 \mu \mathrm{g} \mathrm{mL}^{-1}$ of bismuth(III) in the presence of number of cations and anions within a relative error of $\pm 2 \%$. The results were presented in Table- 2 . The interference of cations was removed by using masking agent, thus making the method more selective.

\section{Applications}

Separation of bismuth(III) from associated metal ions: Pyridine-2-carboxaldehyde 2-hydroxybenzoylhydrazone (PAHB) is used for the separation and determination of

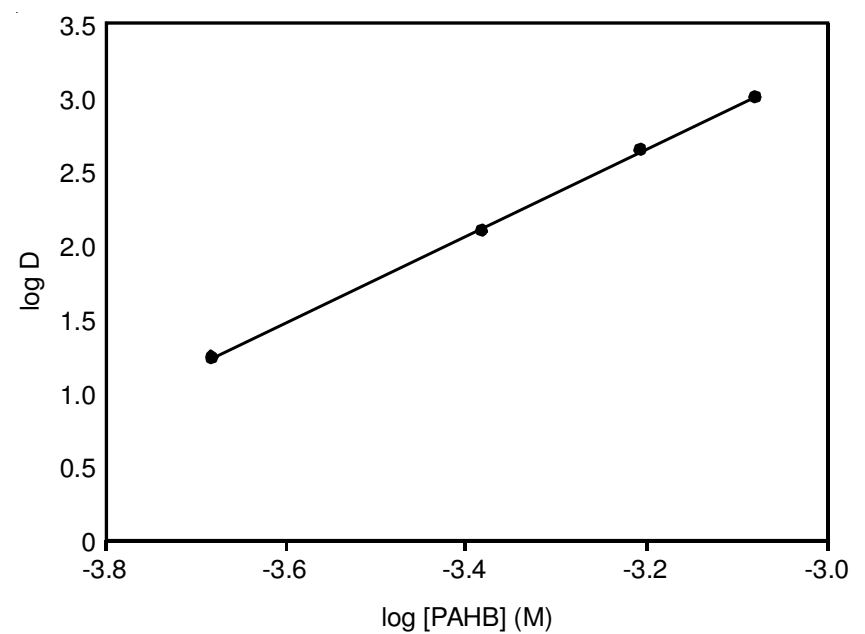

Fig. 4. Plot of composition of the extracted species by slope ratio method

TABLE-2

EFFECT OF FOREIGN IONS ON THE EXTRACTION OF $60 \mu \mathrm{g}$ BISMUTH(III) AT pH 2.0-3.0 FROM $1.0 \mathrm{~mL}$ of $1 \%$ PAHB in DMF EXTRACTED IN CHLOROFORM

\begin{tabular}{|c|c|c|c|}
\hline Foreign ion & $\begin{array}{l}\text { Tolerance } \\
\text { limit (mg) }\end{array}$ & Foreign ion & $\begin{array}{r}\text { Tolerance } \\
\text { limit }(\mathrm{mg})\end{array}$ \\
\hline $\mathrm{Li}(\mathrm{I})$ & 10 & $\mathrm{~Pb}(\mathrm{II})$ & 10.0 \\
\hline $\operatorname{Mg}(\mathrm{II})$ & 10 & $\mathrm{Ce}(\mathrm{IV})$ & 10.0 \\
\hline $\mathrm{Al}(\mathrm{III})$ & 10 & $\operatorname{Th}(\mathrm{IV})$ & 8.50 \\
\hline $\mathrm{V}(\mathrm{V})$ & $2.0^{*}$ & $\mathrm{U}(\mathrm{VI})$ & 0.45 \\
\hline $\mathrm{Cr}(\mathrm{VI})$ & 10.0 & Thiourea & 0.20 \\
\hline $\mathrm{Fe}(\mathrm{III})$ & 2.00 & $\mathrm{~F}^{-}$ & 20.0 \\
\hline Co (II) & 1.65 & $\mathrm{Cl}^{-}$ & 20.0 \\
\hline $\mathrm{Cu}(\mathrm{II})$ & $1.50^{*}$ & $\mathrm{Br}^{-}$ & 20.0 \\
\hline $\mathrm{Zn}(\mathrm{II})$ & 10.0 & $\mathrm{SO}_{3}^{2-}$ & 0.40 \\
\hline As(III) & 10.0 & $\mathrm{SO}_{4}{ }^{2-}$ & 20.0 \\
\hline $\mathrm{Se}(\mathrm{IV})$ & 10.0 & $\mathrm{~S}_{2} \mathrm{O}_{7}^{2-}$ & 20.0 \\
\hline $\mathrm{Zr}(\mathrm{IV})$ & 9.97 & $\mathrm{~S}_{2} \mathrm{O}_{8}{ }^{2-}$ & 20.0 \\
\hline $\mathrm{Mo}(\mathrm{VI})$ & 0.43 & $\mathrm{NO}_{2}^{-}$ & 20.0 \\
\hline $\mathrm{Ni}(\mathrm{II})$ & $1.50^{*}$ & $\mathrm{NO}_{3}^{-}$ & 20.0 \\
\hline $\operatorname{Ag}(\mathrm{I})$ & 10.0 & $\mathrm{ClO}_{3}^{-}$ & 20.0 \\
\hline $\mathrm{Pd}(\mathrm{II})$ & 3.70 & $\mathrm{BrO}_{3}^{-}$ & 20.0 \\
\hline $\mathrm{Cd}(\mathrm{II})$ & 2.00 & $\mathrm{IO}_{3}^{-}$ & 20.0 \\
\hline $\mathrm{Sb}(\mathrm{III})$ & 10.0 & $\mathrm{SCN}^{-}$ & 13.50 \\
\hline $\mathrm{Sn}(\mathrm{II})$ & $2.0^{* * *}$ & Acetate & 20.0 \\
\hline W(VI) & 0.38 & Oxalate & 20.0 \\
\hline $\operatorname{Pt}(\mathrm{IV})$ & 9.20 & Citrate & 20.0 \\
\hline $\mathrm{Au}(\mathrm{III})$ & 4.40 & Tartarate & 20.0 \\
\hline $\mathrm{Tl}(\mathrm{I})$ & 10.0 & Urea & 20.0 \\
\hline
\end{tabular}

*Masked by $1 \mathrm{~mL}$ of $1 \mathrm{M}$ Ammonium thiocyanate, ${ }^{* *}$ Masked by $1 \mathrm{~mL}$ of $0.5 \mathrm{M} \mathrm{Na}$-Tartarate

bismuth(III) from associated metal ions containing $\mathrm{Sn}(\mathrm{II})$, $\mathrm{Fe}(\mathrm{III}), \mathrm{Zn}$ (II), $\mathrm{Sb}$ (III), $\mathrm{Ni}(\mathrm{II}), \mathrm{Cu}$ (II) and $\mathrm{Pb}$ (II) by its extraction with recommended procedure (Table-3).

Determination of bismuth(III) from synthetic mixtures: Several synthetic mixtures of varying compositions containing $40 \mu \mathrm{g}$ of bismuth(III) and associated metal ions of known concentration were added, followed by respective masking reagents. Extraction of bismuth(III) was analyzed by employing the recommended procedure (Table-4). The results obtained were in perfect and good agreement with the amount added.

Determination of bismuth(III) in alloys: Definite amount of alloys was dissolved in concentrated nitric acid and the solution was evaporated almost to dryness. The dried residue 


\begin{tabular}{ccl}
\hline \multicolumn{3}{c}{ TABLE-3 } \\
\multicolumn{3}{c}{ SEPARATION OF BISMUTH(III) } \\
\multicolumn{3}{c}{ FROM ASSOCIATED METAL IONS } \\
\hline Binary mixture & Recovery (\%) & \multicolumn{1}{c}{ Estimation procedure } \\
composition $(\mu \mathrm{g})$ & 99.5 & Pyrocatechol violet \\
\hline $\mathrm{Bi}(\mathrm{II}), 40 ;$ & 99.1 & \\
$\mathrm{Sn}(\mathrm{II}), 50$ & 99.9 & Potassium iodide \\
$\mathrm{Bi}(\mathrm{II}), 40 ;$ & 99.3 & Pyridine-2-acetaldehyde \\
$\mathrm{Sb}(\mathrm{III}), 500$ & 99.8 & salicyloylhydrazone \\
$\mathrm{Bi}(\mathrm{II}), 40 ;$ & 99.7 & Thiocyanate \\
$\mathrm{Pb}(\mathrm{II}), 500$ & 99.3 & \\
$\mathrm{Bi}(\mathrm{II}), 40 ;$ & 99.4 & Dimethylglyoxime \\
$\mathrm{Fe}(\mathrm{III}), 500$ & 99.6 & \\
$\mathrm{Bi}(\mathrm{II}), 40 ;$ & 99.2 & Neo-cuprin \\
$\mathrm{Ni}(\mathrm{II}), 50$ & 99.7 & \\
$\mathrm{Bi}(\mathrm{II}), 40 ;$ & 99.5 & 4-(2-Pyridylazo)resorcinol \\
$\mathrm{Cu}(\mathrm{II}), 50$ & 99.9 & \\
$\mathrm{Bi}(\mathrm{II}), 40 ;$ & 99.5 & \\
$\mathrm{Zn}(\mathrm{II}), 500$ &
\end{tabular}

*Average of five determinations

\begin{tabular}{lc}
\multicolumn{2}{c}{ TABLE-4 } \\
DETERMINATION OF BISMUTH(III) \\
FROM SYNTHETIC MIXTURES \\
\hline Synthetic mixture composition $(\mu \mathrm{g})$ & Recovery of bismuth(III) $(\%)$ \\
\hline $\mathrm{Bi}, 40 ; \mathrm{Sb}, 500 ; \mathrm{As}, 500$ & 99.94 \\
$\mathrm{Bi}, 40 ; \mathrm{Tl}, 500 ; \mathrm{Pb}, 500$ & 99.80 \\
$\mathrm{Bi}, 40 ; \mathrm{Sn}, 50 ; \mathrm{Pb}, 500$ & 99.70 \\
$\mathrm{Bi}, 40 ; \mathrm{Fe}, 500 ; \mathrm{Sn}, 50$ & 99.50 \\
$\mathrm{Bi}, 40 ; \mathrm{Sb}, 500 ; \mathrm{Te}, 500$ & 99.90 \\
$\mathrm{Bi}, 40 ; \mathrm{Sn}, 50 ; \mathrm{Sb}, 500$ & 99.50 \\
\hline
\end{tabular}

taken up in the dilute nitric acid. Any metastannic acid which was form in the solution was filtered off and washed with hot dilute nitric acid and finally with hot water. The filtrate was collected and diluted to $100 \mathrm{~mL}$ with distilled water. A definite aliquot of the above solution was used to extract and determine bismuth by the recommended procedure. The results obtained were compared with those of atomic absorption spectrophotometry (Table-5).

Determination of bismuth(III) from drug samples: The proposed method was applied for determination of bismuth(III) in Tablet of Denol (Elder Pharma Ltd) and Pylocid (E. Merck Ltd), which are used the treatment of peptic ulcers, were taken separately in beaker and dissolved in $10 \mathrm{~mL}$ of perchloric acid and evaporated to nearly dryness. The dried mass dissolved in distilled water containing $1 \mathrm{~mL}$ of nitric acid. The solution was filtered through whatman filter paper 42 and filtrate was diluted to $100 \mathrm{~mL}$ with distilled water. An aliquot of each of the above solution was taken for the estimation of bismuth by recommended procedure. The results obtained were compared with those obtained by atomic absorption spectrophotometry (Table-6).

\section{Conclusion}

The synthesized reagent pyridine-2-carboxaldehyde-2hydroxybenzoylhydrazone (PAHB) has been proved to be highly sensitive for extraction and spectrophotometric determination of bismuth(III). It is observed to be applicable for the determination of bismuth(III) in binary, synthetic mixtures and various real samples with satisfactory results. Salient futures such as (i) trace concentration of bismuth(III) can determined. (ii) The developed extraction procedure is a single stage. (iii) The yellow-green coloured complex is stable for 6 days. (iv) Pyridine-2-carboxaldehyde 2-hydroxybenzoylhydrazone (PAHB) form complex with bismuth(II) in acidic medium and extracted in chloroform probable stoichiometry of extracted species as 1:3 (M:L). (v) The present method does not face the problem of interference due to foreign ions to greater extent. (vi) The developed method is simple, reproducible, rapid, selective and used for separation and determination of bismuth(III) in real samples and synthetic mixtures of associated metal ions.

\section{REFERENCES}

1. E. Kilinc, Anal. Methods, 7, 10306 (2015); https://doi.org/10.1039/C5AY02660A.

2. S. Rastegarzadeh, N. Pourreza and A. Larki, Anal. Methods, 6, 3500 (2014);

https://doi.org/10.1039/c4ay00526k.

3. A.C. Fornieles, A.G. de Torres, E.I. Vereda Alonso and J.M.C. Pavón, J. Anal. At. Spectrom., 28, 364 (2013); https://doi.org/10.1039/c2ja30337j.

4. X. Jia, Y. Han, X. Liu, T. Duan and H. Chen, Mikrochim. Acta, 171, 49 (2010); https://doi.org/10.1007/s00604-010-0402-5.

5. H. Sereshti, Y. Entezari Heravi and S. Samadi, Talanta, 97, 235 (2012); https://doi.org/10.1016/j.talanta.2012.04.024.

6. M. Sun and Q. Wu, J. Hazard. Mater., 192, 935 (2011); https://doi.org/10.1016/j.jhazmat.2010.11.044.

\begin{tabular}{|c|c|c|c|c|}
\hline \multicolumn{5}{|c|}{$\begin{array}{c}\text { TABLE-5 } \\
\text { DETERMINATION OF BISMUTH(III) IN ALLOYS }\end{array}$} \\
\hline Sample & Composition & $\begin{array}{l}\text { Certified value of } \\
\text { bismuth }\end{array}$ & $\begin{array}{l}\text { Bismuth found by } \\
\text { PAHB method }\end{array}$ & $\begin{array}{l}\text { Bismuth found by } \\
\text { AAS method }\end{array}$ \\
\hline $\begin{array}{l}\text { ALLOYS Bi-Alloy } \\
\text { (ITA Lab. 4139/3) }\end{array}$ & $\begin{array}{l}\mathrm{Bi}, 49.1 ; \mathrm{Pb}, 26.58 ; \mathrm{Sn}, 14.74 ; \mathrm{Cd}, 9.52 ; \mathrm{Fe} \\
0.05 ; \mathrm{Zn}, 0.01\end{array}$ & 49.1 & 49.1 & 49.1 \\
\hline $\begin{array}{l}\text { Tin Base White } \\
\text { Metal [BSC 178/2] }\end{array}$ & $\begin{array}{l}\mathrm{Bi}, 0.11 ; \mathrm{Sn}, 82.2 ; \mathrm{Sb}, 9.45 ; \mathrm{Cu}, 4.58 ; \mathrm{Pb}, 3.18 \\
\mathrm{Ni}, 0.17 ; \mathrm{As}, 0.15 ; \mathrm{Cd}, 0.14 ; \mathrm{Zn}, 0.04 ; \mathrm{Fe}, 0.024\end{array}$ & - & $109 \mu \mathrm{g} / \mathrm{mL}$ & 110 \\
\hline
\end{tabular}

TABLE-6

DETERMINATION OF BISMUTH(III) IN DRUGS

\begin{tabular}{|c|c|c|c|}
\hline Sample & Certified value of mercury & Bismuth found by PAHB method & Bismuth found by AAS method \\
\hline Denol [Elder Pharma Ltd.] & $107.63 \mathrm{mg} /$ Tablet & 107.54 & 107.62 \\
\hline Pylocid [E. Merck Ltd., India] & $107.63 \mathrm{mg} /$ Tablet & 107.58 & 107.63 \\
\hline
\end{tabular}


7. A. Koper and M. Grabarczyk, J. Electroanal. Chem., 681, 1 (2012); https://doi.org/10.1016/j.jelechem.2012.05.020.

8. M.H. Pournaghi-Azar, D. Djozan and H. Abdolmohammad Zadeh, Anal. Chim. Acta, 437, 217 (2001); https://doi.org/10.1016/S0003-2670(01)00973-4.

9. V.P. Gordeeva, M.A. Statkus, G.I. Tsysin and Y.A. Zolotov, Talanta, 61, 315 (2003); https://doi.org/10.1016/S0039-9140(03)00271-6.

10. B. Zawisza and R. Sitko, Spectrochim. Acta B At. Spectrosc., 62, 1147 (2007); https://doi.org/10.1016/j.sab.2007.07.004.

11. P.D. Tzanavaras, D.G. Themelis and A. Economou, Anal. Chim. Acta, 505, 167 (2004); https://doi.org/10.1016/S0003-2670(03)00017-5.

12. P. Carrero, L. Gutierrez, C. Rondon, J.L. Burguera, M. Burguera and Y.P. de Pena, Talanta, 64, 1309 (2004); https://doi.org/10.1016/j.talanta.2004.05.061.

13. X. Wen, Y. Zhao, Q. Deng, S. Ji, X. Zhao and J. Guo, Spectrochim. Acta A Mol. Biomol. Spectrosc., 89, 1 (2012); https://doi.org/10.1016/j.saa.2011.12.041.

14. S. Sahan, S. Sacmaci, U. Sahin, A. Ulgen and S. Kartal, Talanta, 80, 2127 (2010); https://doi.org/10.1016/j.talanta.2009.11.019.

15. J.L. Burguera, M. Burguera, C. Rivas, C. Rondon, P. Carrero and M. Gallignani, Talanta, 48, 885 (1999); https://doi.org/10.1016/S0039-9140(98)00298-7.
16. B. Medjahed, M.H. Kaid, M.A. Didi and D. Villemin, Int. J. Nonferr. Metall., 1, 59 (2012); https://doi.org/10.4236/ijnm.2012.13008.

17. D.D. Malkhede, P.M. Dhadke and S.M. Khopkar, Indian J. Chem. Technol., 7, 7 (2000).

18. J.G. Yang, J.Y. Yang, M.T. Tang, C.B. Tang and W. Liu, Hydrometallurgy, 96, 342 (2009); https://doi.org/10.1016/j.hydromet.2008.12.006.

19. S.G. Sarkar and P.M. Dhadke, Sep. Purif. Technol., 15, 131 (1999); https://doi.org/10.1016/S1383-5866(98)00088-4.

20. S. Facon, G. Cote and D. Bauer, Solvent Extr. Ion Exch., 9, 717 (1991); https://doi.org/10.1080/07366299108918080.

21. J.B. Headridge and J. Richardson, Analyst, 95, 930 (1970); https://doi.org/10.1039/an9709500930.

22. K. Venkaji, P.P. Naidu and T.J.P. Rao, Talanta, 41, 1281 (1994); https://doi.org/10.1016/0039-9140(94)E0008-F.

23. S.D. Shete and V.M. Shinde, Mikrochim. Acta, 82, 63 (1984); https://doi.org/10.1007/BF01202162.

24. S.D. Dhanvate, D.J. Garole and A.D. Sawant, J. Mater. Environ. Sci., 6, 519 (2015).

25. A.K. Singh and S. Sharma, Microchem. J., 35, 365 (1987); https://doi.org/10.1016/0026-265X(87)90124-X.

26. Z. Marczenco, Spectrophometric Determination of Elements, Ellis Hardwood, Chichester, p. 125 (1976). 